\title{
Ceratothripoides claratris, a New Vector of a Capsicum chlorosis virus Isolate Infecting Tomato in Thailand
}

\author{
W. T. S. D. Premachandra, C. Borgemeister, E. Maiss, D. Knierim, and H.-M. Poehling
}

Institute of Plant Diseases and Plant Protection, University of Hanover, Herrenhäuser Str. 2, 30419 Hanover, Germany; and first author: University of Ruhuna, Matara, Sri Lanka. Accepted for publication 22 February 2005.

\begin{abstract}
Premachandra, W. T. S. D., Borgemeister, C., Maiss, E., Knierim, D., and Poehling, H.-M. 2005. Ceratothripoides claratris, a new vector of a Capsicum chlorosis virus isolate infecting tomato in Thailand. Phytopathology 95:659-663.

Ceratothripoides claratris, the predominant thrips species on tomato in Thailand, was tested for vector competence and efficiency to transmit Capsicum chlorosis virus ( $\mathrm{CaCV}$ ) (isolate AIT) to tomato. The efficiency of adult-stage transmission was influenced by the larval stage at which virus was acquired. Adult $C$. claratris showed $69 \%$ transmission effi-

(48\%). Transmission efficiency of up to $47 \%$ was detected with secondinstar larvae of $C$. claratris which had acquired the virus as freshly emerged first-instar larvae. Transmission efficiency did not significantly differ between adult males and females, irrespective of the larval stage at which the virus was acquired. Highest transmission efficiency for $\mathrm{CaCV}$ was recorded in adult $C$. claratris derived from second-instar larvae collected from infected tomato plants in a greenhouse. Lowest transmission efficiency was observed in adults directly collected from infected tomato plants in the greenhouse. The spread of $\mathrm{CaCV}$ on tomato plants in greenhouses showed a close association with thrips infestations.
\end{abstract} ciency after acquiring the virus as freshly emerged $(<1 \mathrm{~h})$ first-instar larvae. However, when just molted $(<1 \mathrm{~h})$ second-instar larvae acquired the virus, the percentage of adult transmitters significantly decreased
Additional keyword: tospovirus.
Tospoviruses (genus Tospovirus; family Bunyaviridae) cause severe losses in various economically important crops $(1,3,18)$. Tospoviruses are exclusively transmitted by several thrips species in a persistent propagative manner $(20,30)$. The first-instar larvae acquire virus from viruliferous plants $(4,19,22,23)$ and, after a latent period, tospoviruses may be transmitted by second-instar larvae and adults $(13,29)$. Of the $\approx 5,500$ known species of Thysanoptera, $<10$ have been verified as vectors of tospoviruses (21).

Since 2001, tomato plants in fields and greenhouses at the Asian Institute of Technology (AIT) in Bangkok, Thailand showed symptoms consistent with a severe tospovirus infection. Serological studies confirmed that the virus belongs to serogroup IV of tospoviruses. Amino acid sequence analysis of the N-gene (accession no. AY846366) revealed 92\% identity with the recently described Capsicum chlorosis virus $(\mathrm{CaCV})$ from Queensland, Australia (6). In addition, similar tospovirus infections have been recorded in northeastern Thailand (9). The predominant thrips species on field- and greenhouse-grown tomato in central Thailand in general and in the greater Bangkok area in particular is Ceratothripoides claratris (Shumsher) (Thysanoptera: Thripidae) $(8,10,12)$. Moreover, symptoms of tospovirus infections on tomato always were associated with the presence of this thrips species. Severe $C$. claratris infestations in young tomato plants, coupled with virus infection, resulted in the death of the plants prior to fruit set (D. Premachandra, unpublished data). Thus, we hypothesized that $\mathrm{CaCV}$ is vectored by $C$. claratris. The principal objective of this research was to verify vector competence of $C$. claratris in transmitting this tospovirus isolate. In addition, acquisition of the virus by first- and second-instar larvae and transmission

Corresponding author: C. Borgemeister

E-mail address: borgemeister@ipp.uni-hannover.de

DOI: 10.1094/PHYTO-95-0659

(C) 2005 The American Phytopathological Society efficiencies of second-instar larvae and adults were studied under laboratory conditions. Finally, spread of the virus and infestation pattern of $C$. claratris were investigated under greenhouse conditions at AIT, and the transmission efficiency of thrips larvae and adults collected from infected tomato plants in the greenhouse was determined.

\section{MATERIALS AND METHODS}

Thrips. Initially, specimens of $C$. claratris were identified by R. zur Strassen based on morphological characteristics, and voucher specimens were deposited at the Senckenberg Museum, Frankfurt, Germany. Virus-free C. claratris colonies were reared on potted tomato plants (Lycopersicon esculentum Mill, cv. King Kong II) in thrips-proof cages at $25 \pm 2{ }^{\circ} \mathrm{C}$ and a 12 -h daily photoperiod. The colony originally was started from adult $C$. claratris collected from tomato plants at AIT. For the acquisition tests, synchronized-aged first- (L1) and second-instar (L2) larvae were obtained by allowing female $C$. claratris $(\approx 500)$ to oviposit on excised healthy tomato leaflets for $4 \mathrm{~h}$ in a sealed petri dish $(8.5$ by $1.5 \mathrm{~cm}$ ) containing, on the bottom, a 1-cm layer of a mixture of plaster of Paris $\left(\mathrm{CaSO}_{4}\right)$ and charcoal (ratio 9:1), following the protocol developed by Premachandra et al. (10). A mixture of plaster of Paris and charcoal creates a solid surface which can retain moisture and provided a good substrate for the experiments. To keep detached leaflets viable, the petioles were wrapped with water-soaked cotton. Adult thrips were removed from the leaflets with a fine, camel-hair brush and the eggs were allowed to develop to L1 or L2. The L2 stage was determined by the occurrence of an exuvia.

Tospovirus isolate and test plants. $\mathrm{CaCV}$ isolate AIT $(\mathrm{CaCV}$ AIT) originally was detected in greenhouse-grown tomato plants (cv. King Kong II). The virus was propagated and maintained by mechanical inoculation in Nicotiana benthamiana Domin. Inoculations were conducted at the five-leaf stage with sap of infected 
tomato or $N$. benthamiana leaves ground in $0.01 \mathrm{M}$ phosphate buffer (ratio 5:1), $\mathrm{pH} 7.0$, containing $0.1 \%$ sodium sulfite and a small amount of Celite as an abrasive. In the acquisition experiments, 2-week-old tomato seedlings (cv. King Kong II) were mechanically inoculated with extracts of systemically infected leaves of $N$. benthamiana plants. Both tomato and $N$. benthamiana plants were grown at $25 \pm 2{ }^{\circ} \mathrm{C}$ and a 12 -h daily photoperiod. Tomato leaflets showing systemic symptoms, generally appearing 14 to 21 days after mechanical inoculation, were selected for the acquisition tests.

Virus detection by enzyme-linked immunosorbent assay. Double-antibody sandwich enzyme-linked immunosorbent assay (DAS-ELISA) $(2,11)$ was conducted for the detection of CaCVAIT in leaf extracts of infected $N$. benthamiana and tomato plants, and to confirm infection in tomato leaf disks used for transmission tests. A mixture of poly- and monoclonal antibodies raised against the N-proteins of Watermelon silver mottle virus (WSMoV) and Groundnut bud necrosis virus (GBNV) (Agdia, Inc., Elkhart, IN) were used. Antibodies and conjugated antibodies were applied at the recommended concentration of 1:200 ( $\mathrm{vol} / \mathrm{vol}$ ). Plant extracts were prepared by homogenizing leaf material with PBS-T $\left(2.5 \mathrm{mM} \mathrm{KCl}, 1 \mathrm{mM} \mathrm{KH} \mathrm{PO}_{4}, 8 \mathrm{mM} \mathrm{Na}_{2} \mathrm{HPO}_{4}\right.$, $0.14 \mathrm{M} \mathrm{NaCl}$, and Tween 20 at $0.5 \mathrm{ml} / \mathrm{liter}$ ) at $\approx 200 \mathrm{mg} / \mathrm{ml}$ containing polyvinylpyrrolidone K25 (PVP) at $20 \mathrm{~g} /$ liter. Leaf disks from healthy $N$. benthamiana and tomato plants were used as controls. Absorbance values at $405 \mathrm{~nm}\left(A_{405}\right)$ were determined with an EL 312 ELISA-reader (BIO-Tek Instruments). Wells containing only PBS-T in the sample incubation step were used as controls. The $A_{405}$ values were corrected by subtracting the mean (average of three wells) of the buffer control absorbance values from sample values. Samples having absorbance values three times higher than the standard deviation of the healthy controls were considered as positive.

Virus acquisition by first- and second-instar larvae and transmission by adults. The ability to acquire $\mathrm{CaCV}$ by $\mathrm{L} 1$ and L2 of $C$. claratris was determined by the subsequent capability of emerging adults to transmit virus. Newly emerged $(<1 \mathrm{~h}) \mathrm{Ll}$ and just-molted L2 from the same cohort were given an acquisition access period (AAP) until pupation on systemically infected tomato leaflets with equally high virus titers. For the latter, prior to the transmission tests, virus titer in the apical part of the leaflets was first checked by DAS-ELISA. For leaflets with high virus titer, the remaining part of the leaflet then was used for the AAP tests. Groups of L1 and L2 (at least 40 in each category) were separately placed on infected tomato leaflets. First-instar larvae were reared until the L2 stage on virus-free tomato leaves (cv. King Kong II). For C. claratris, late L2 drop from the foliage to pupate in soil or in leaf litter. A water-filled petri dish $(8.5$ by $1.5 \mathrm{~cm}$ ) was placed beneath leaflets to collect larvae and checked every $6 \mathrm{~h}$ for the presence of thrips larvae. L1 and L2 reared on virus-free tomato leaflets were used as controls. The collected larvae were reared until adulthood in small plastic containers ( 5 by 4 by $3 \mathrm{~cm}$ ) containing, on the bottom, a $1.5-\mathrm{cm}$ layer of a mixture of plaster of Paris and charcoal (9:1) and held at $25 \pm$ $2{ }^{\circ} \mathrm{C}, 60$ to $70 \%$ relative humidity (RH), and a 12 -h daily photoperiod. The sex of adult thrips was determined upon emergence. Transmission efficiency of individual adult thrips (i.e., both males and females) was determined in three successive inoculation access periods (IAP) of $48 \mathrm{~h}$ each (i.e., first IAP, age class 0 to 2 days old; second IAP, age class 3 to 5 days old; and third IAP, age class 6 to 8 days old) on leaf disks (diameter $\approx 10 \mathrm{~mm}$ ) from healthy tomato plants placed in 2-ml plastic tubes. After each IAP, the leaf disks were incubated on tap water for 6 days in 24-well plates (Costar Europe Ltd., Badhoevedorp, The Netherlands) at $25 \pm 2{ }^{\circ} \mathrm{C}$. Infection of the leaf disks was estimated by development of local necrosis and subsequently confirmed by DASELISA at the end of the incubation period. At least 30 adult thrips which had acquired $\mathrm{CaCV}$ during L1 and L2 instars were tested individually on tomato leaf disks and the experiment was repeated three times. The rate of virus transmission was calculated as the percentage of leaf disks infected. Adult thrips that showed virus transmission at least once during one of the three IAPs or age classes were considered viruliferous.

Virus transmission by adult $C$. claratris also was determined on tomato seedlings covered by Plexiglas cylinders (i.e., in a microcosm) providing thrips with an IAP of 5 days at $25 \pm 2{ }^{\circ} \mathrm{C}$. Previously, L1 were given an AAP until pupation on infected tomato leaflets and reared until adult emergence following the protocols described previously. Adults reared on healthy tomato leaves were used as a control. Two-week-old potted tomato seedlings were covered with Plexiglas cylinders (diameter $10 \mathrm{~cm}$, height $30 \mathrm{~cm}$ ). The upper opening of the cylinder was closed with thrips-proof nylon gauze $(64-\mu \mathrm{m}$ mesh size). In addition, four holes were drilled at the upper and lower edges of the cylinder and, except for one hole at the lower edge, all other holes were covered with thrips-proof nylon gauze to aid ventilation. The lower uncovered hole was used for releasing adult thrips into the cylinders and subsequently was covered with tape. After the IAP, the cylinder was removed and the seedlings were sprayed with spinosad (12\%, wt/vol SC; Dow Agrosciences, Indianapolis, IN) and kept at $25 \pm 2{ }^{\circ} \mathrm{C}, 60$ to $70 \% \mathrm{RH}$, and a 12 -h daily photoperiod for symptom development. Percentage of infected tomato plants was recorded on the basis of visual symptoms (brown necrotic spots) and later confirmed by DAS-ELISA. The trial was repeated three times with a minimum of 30 thrips per repetition.

Virus acquisition by first-instar larvae and transmission by second-instar larvae. In this experiment, the ability of L2, which acquired the virus as $\mathrm{L} 1$, to transmit $\mathrm{CaCV}$ was determined on tomato leaf disks. After adult emergence, the transmission efficiency of unsexed adult thrips also was tested. Cohorts (at least 15) of newly emerged L1 were given an AAP on virus-infected tomato leaflets until molting to the L2 stage. Immediately after molting, L2 were transferred individually to healthy tomato leaf disks floating on tap water in 24-well plates and allowed to feed until pupation. Thereafter, the prepupae were moved to small plastic containers and reared until adulthood. The leaf disks were incubated for 6 days and virus infection was assessed by DASELISA. Adult-stage transmission efficiency was determined as described previously. Thrips larvae reared on healthy tomato leaves were used as control treatments. The experiment was repeated three times with a minimum of 10 thrips per repetition.

Greenhouse trials. Two trials were conducted in a $200-\mathrm{m}^{2}$, closed nethouse (Econet M, pore size $0.18 \mathrm{~mm}$; Ludvig Svensson Inc., Kinna, Sweden), subdivided into two partitions. The experiments were carried out between January and March 2003 and between June and August 2004. Only one partition of the nethouse (i.e., $100 \mathrm{~m}^{2}$ ) was used for the trials with 180 3-week-old potted (30 by $25 \mathrm{~cm}$ ) tomato seedlings (cv. King Kong II) arranged in three rows with no interpot distance within a row. The distance between rows was $160 \mathrm{~cm}$. During the trials, mean temperature and $\mathrm{RH}$ were 28 to $30^{\circ} \mathrm{C}$ and 70 to $80 \%$, respectively. Plants were irrigated and fertilized seven to nine times per day with an automated drip irrigation system. Tomato plants in this greenhouse were naturally infested by $C$. claratris. At 1 week post-planting (WPP), thrips density (larvae and adults) on tomato leaves was estimated using destructive sampling methods. On each sampling date, one leaf sample per plant from 10 randomly selected plants per row was taken. Sampling continued for 9 consecutive weeks. The number of virus-infected plants was recorded based on the presence of visual symptoms (brown lesions on the leaves and ring spots on fruits) in each row at all sampling dates. At least five leaf samples per plant were tested by DAS-ELISA to confirm virus infection. During the second trial, adult thrips were collected randomly from tomato plants showing signs of a tospovirus infection 5 WPP, and vector competence was investigated using the tomato leaf-disk assay. Moreover, late L2 were collected 
in the same week from tomato plants showing symptoms of tospovirus infection. Additionally, plant leaf samples were taken and virus infection was verified by DAS-ELISA. The thrips were reared in the laboratory until adulthood and tested for transmission efficiency using the tomato leaf-disk assay. These tests were repeated at least three times with 35 thrips larvae and adults per repetition.

Statistical analysis. Percent transmission data were subjected to Shapiro-Wilk's test for normality and Brown and Forsythe's test for homogeneity of variance. Whenever normality and variance homogeneity were violated, data were subjected to arcsine transformation. Subsequently, transmission efficiencies among the sexes and life stages were compared using Student's $t$ test and analysis of variance (ANOVA) (15).

\section{RESULTS}

Virus acquisition by first- and second-instar larvae of $C$. claratris and transmission by adults. Adult $C$. claratris that had been kept as L1 on virus-infected tomato leaflets transmitted $\mathrm{CaCV}$ to tomato leaf disks and plants at rates of 69 and $64 \%$, respectively (Table 1). Transmission efficiency did not differ significantly between the two assay methods $(t=0.86, P=0.4374)$. When using the leaf-disk method, acquisition by L1 and L2 resulted in transmission efficiencies of 68.7 and $48.4 \%$ by the emerging adults, respectively, which differed significantly $(t=$ $3.36, P=0.0283$ ). Transmission efficacy did not differ significantly between the sexes (Table 1). No significant differences were detected in transmission rates of each sex among the three IAPs or age classes, implying there was no increase in transmission rates with increasing age (Fig. 1). All thrips that had transmitted the virus in one IAP or age class transmitted the virus in the subsequent IAPs or age classes. With 63 and $78 \%$ for females and males, respectively, significantly higher proportions of thrips transmitted the virus three times during the three IAPs or age classes (females: $F=188.79$, df $=2,6, P<0.0001$; males: $F=$ $126.76, \mathrm{df}=2,6, P<0.0001)$ than twice (females $=2 \%$, males $=$ $3 \%$ ) or only once (females $=1 \%$, males $=1 \%$ ).

Virus acquisition by first-instar larvae and transmission by second-instar larvae. In tomato leaf-disk assays, L2 C. claratris transmitted $\mathrm{CaCV}$ with an efficiency of $47 \pm 5.68 \%$ compared with $66 \pm 2.76 \%$ in adults, the latter being significantly higher than the former $(t=2.95, P=0.0419)$. Of thrips studied, $39 \%$ did not transmit the virus as L2 or adults. All thrips that had already transmitted the virus as L2 also transmitted it as adults.

Thrips density and spread of the virus in the greenhouse. In both trials, C. claratris infestations commenced 1 WPP of the tomato seedlings (Fig. 2). Thrips density in the first trial was considerably higher than in the second trial. In the first trial, peak thrips density was recorded at 5 WPP and was followed by a sharp decline. In the second trial, thrips densities remained constant over time. In both trials, tomato plants began to show symptoms of tospovirus infection 4 WPP. In the first trial, the proportion of virus-infected plants exceeded $50 \%$ at $5 \mathrm{WPP}$; whereas, in the second trial, it took 8 weeks for at least $50 \%$ of the tomato plants to become symptomatic. At the end of the observation period, $>75 \%$ of the plants showed symptoms of tospovirus infection for both trials (Fig. 2).

Transmission tests with greenhouse-collected thrips. Adult C. claratris, which matured from L2 collected from infected tomato plants in the nethouse, transmitted $\mathrm{CaCV}$ at a rate of $87 \%$ to tomato leaf disks. In contrast, adults directly collected from infected tomato plants transmitted the virus at a significantly lower rate (Table 2). As in the previous experiment, transmission efficiency of the virus did not differ significantly between the sexes (Table 2).

\section{DISCUSSION}

Our results clearly demonstrate that $C$. claratris is an efficient vector of CaCV-AIT to tomato. Tomato cv. King Kong II proved to be a suitable host plant for $C$. claratris and highly susceptible to $\mathrm{CaCV}$-AIT. In preliminary experiments, we found that, following mechanical inoculation, the two tobacco species $N$. benthamiana and $N$. glutinosa L. supported propagation of the virus. However, both Nicotiana spp. caused $100 \%$ larval mortality, such that no thrips survived to maturity. This result suggests that both species are toxic to $C$. claratris. Moreover, we recorded reduced feeding preference of $C$. claratris and propagation of CaCV-AIT on Petunia hybrids compared with tomato (data not shown). Thus, the compatibility of the virus isolate, thrips, and host plant species used for the acquisition and inoculation experiments explains the

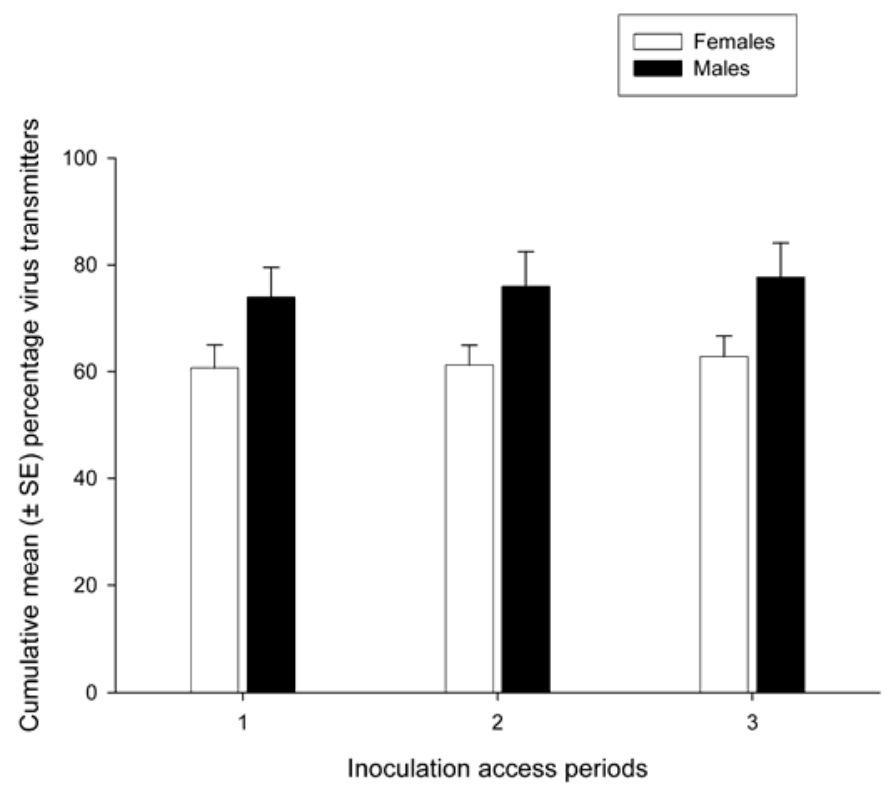

Fig. 1. Cumulative mean ( \pm standard error $[\mathrm{SE}])$ percentage of female and male Ceratothripoides claratris transmitting Capsicum chlorosis virus $(\mathrm{CaCV})$ per inoculation access period (IAP). Adult thrips of different age classes (i.e., first IAP, age class 0 to 2 days old; second IAP, age class 3 to 5 days old, and third IAP, age class 6 to 8 days old) were confined for $48 \mathrm{~h}$ on leaf disks from healthy tomato plants. Thrips previously had acquired the virus during the first larval stage and had been provided with an acquisition period until pupation.

TABLE 1. Transmission efficiency of a Capsicum chlorosis virus (CaCV) Asian Institute of Technology (AIT) isolate (CaCV-AIT) on tomato leaf disks and whole plants by adult Ceratothripoides claratris ${ }^{\mathrm{y}}$

\begin{tabular}{|c|c|c|c|c|c|}
\hline \multirow[b]{2}{*}{ Acquisition life-stage } & \multirow[b]{2}{*}{ Assay method } & \multirow[b]{2}{*}{ Repetitions } & \multicolumn{3}{|c|}{ Mean $\left( \pm\right.$ SE) transmission by adult thrips $(\%)^{\mathrm{z}}$} \\
\hline & & & Female & Male & Total \\
\hline First-instar larvae & Leaf-disk assay & 3 & $62.85 \pm 1.98(87) \mathrm{a}$ & $77.69 \pm 9.30(38) \mathrm{a}$ & $68.67 \pm 4.48(125)$ \\
\hline First-instar larvae & Whole-plant assay & 3 & $63.58 \pm 2.29(57) \mathrm{a}$ & $73.00 \pm 4.77(36) \mathrm{a}$ & $64.46 \pm 2.23(93)$ \\
\hline Second-instar larvae & Leaf-disk assay & 3 & $51.52 \pm 3.33(54) \mathrm{a}$ & $40.28 \pm 5.00(20) \mathrm{a}$ & $48.43 \pm 3.92(74)$ \\
\hline
\end{tabular}

${ }^{y}$ Both first and second instar larvae were given an acquisition period until pupation on virus-infected tomato leaves.

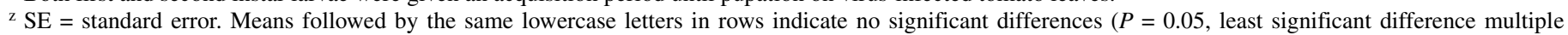
range test) (SAS Institute 1999). Numbers in parentheses represent sample size. 
high transmission efficiency recorded in this study. Moreover, we observed almost identical virus transmission efficiency using the leaf-disk and whole-plant assay methods. However, $\approx 10$ to 14 or 5 to 6 days were needed to detect the virus by DAS-ELISA in the whole-plant and leaf-disk assay methods, respectively, indicating that the latter assay was simpler.

Transmission efficiency of adult $C$. claratris was influenced by the larval stage at which $\mathrm{CaCV}$ was acquired. The percentage of adult transmitters decreased when the virus was acquired during L2, suggesting a lower virus acquisition rate of L2 compared with L1. Transmission efficiency of Tomato spotted wilt virus (TSWV) and Impatiens necrotic spot virus (INSV) by Frankliniella occidentalis (Pergande) (Thysanoptera: Thripidae) decreased with the age at which larvae had acquired virus (26), corroborating our findings. However, the ability of larval instars to acquire virus greatly depends on the thrips species or population as well as on the virus isolates tested $(4,19,26,27)$. The lower acquisition rate of $C$. claratris L2 may be associated with the presence of midgut barriers that prevent virus from reaching salivary glands, thereby preventing subsequent virus replication and transmission $(7,24)$

Our results showed that $\mathrm{L} 2$ of $C$. claratris can transmit CaCVAIT after acquisition during L1. Moreover, $19 \%$ of the thrips that failed to transmit the virus as L2 subsequently were able to transmit as adults, indicating that these adults had become viruliferous immediately upon adult emergence (29). Virus transmission by L2 C. claratris is particularly important because these larvae can migrate between plants in contact with each other (29). C. claratris has a high reproduction capacity at warm temperatures frequently prevailing in tropical greenhouses (10). Hence, transmission ability of L2 of $C$. claratris could contribute to secondary spread of the virus.

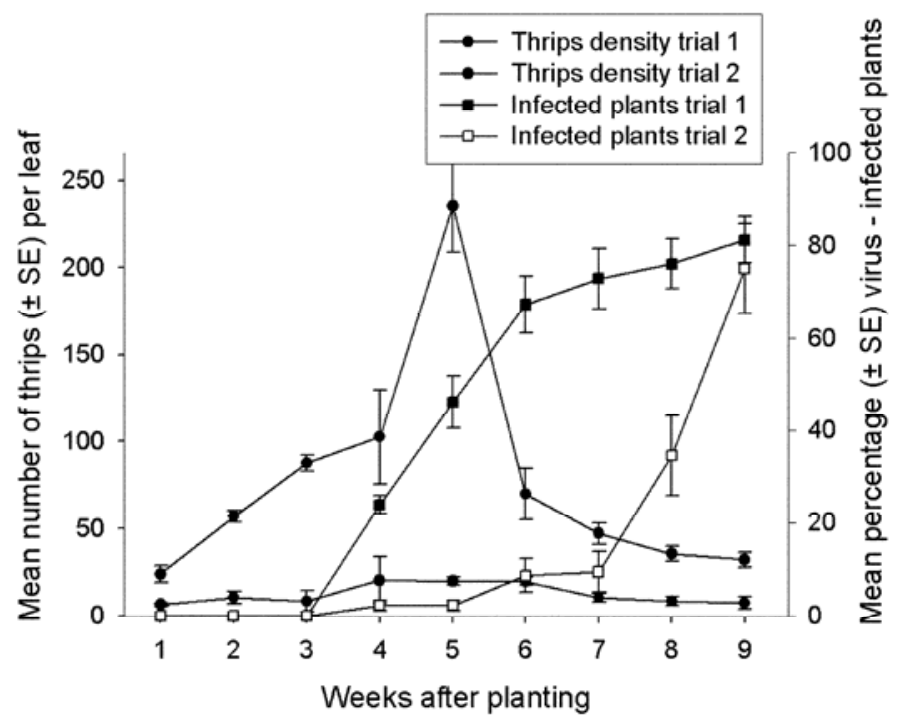

Fig. 2. Mean ( \pm standard error [SE]) density of Ceratothripoides claratris on tomato leaves and mean $( \pm \mathrm{SE})$ cumulative percentage of infested tomato plants recorded in two trials in a nethouse over a period of 9 weeks.
Adult male and female $C$. claratris did not differ in transmission competency, corroborating findings of previous studies with F. occidentalis and TSWV $(14,17)$. This observation suggested that the latent period terminates with the L2 stage. Conversely, Van de Wetering et al. $(25,26)$ detected higher transmission efficiency of TSWV by male thrips of $F$. occidentalis. Differences in tospovirus transmission between male and female adult thrips may depend on feeding behavior (25), and on virus titer and physiological condition of the vectors (14).

Virus transmission of both adult female and male $C$. claratris commenced 0 to 2 days after emergence, implying that latent periods of both males and females were brief. In F. occidentalis, concentration of TSWV particles in adults reached maximum levels 4 days after adult emergence and transmission efficiency decreased with age (26). In our studies, adult $C$. claratris retained vector competency for at least 8 days after adult emergence.

In both nethouse trials, natural infestation by $C$. claratris commenced 1 WPP, indicating that the net could not exclude thrips invasion from the outside. Symptoms of a tospovirus infection first appeared on tomato plants 4 WPP, strongly suggesting that the tospovirus infection was initiated by viruliferous $C$. claratris that had invaded the nethouses from outside. Seed transmission has been ruled out for TSWV (5) and, for other tospoviruses, no data are available. The differences in thrips densities between the two trials most likely were associated with seasonal effects. Relatively low $C$. claratris densities occurred during the rainy season (April to September) compared with the dry season (October to March), which is in agreement with previous findings (12). The level of thrips densities influenced initiation and subsequent spread of virus in the nethouses. Thus, after invasion of viruliferous thrips into the nethouses, the prevailing microclimatic conditions (i.e., high temperatures and relative humidity) inside the nethouse provided highly favorable conditions for growth and reproduction of $C$. claratris (10). Consequently, the few initially infected tomato plants may have served as potential virus sources for the newly emerged thrips larvae which, in turn, spread the virus as adults. In addition to adult thrips, L2 $C$. claratris also could have contributed to the spread of the virus infection because the arrangement of the pots in the nethouse allowed plant contact.

We recorded high efficiency of virus transmission (up to $87 \%$ ) by adults emerging from L2 that previously had been collected from infected tomato plants in the nethouse, possibly because of high virus titer in second-instar larvae. Wijkamp and Peters (27) reported that in F. occidentalis TSWV particles replicated in firstand second-instar larvae. In addition, virus replication and movement of tospoviruses are greater within vectors at higher temperatures (16). The lowest virus transmission rate was recorded in C. claratris adults collected from infected tomato plants in the nethouse. At the time of collection, very low numbers of adults were present on leaves, and most of the thrips were collected from fruit of infected plants. Moreover, many of the collected thrips showed abnormalities, especially on their legs and wings, indicating that they either were at the end of their life span or had suffered due to deterioration of host plant quality. Although viruliferous thrips can transmit the virus until death (28), young adults of $F$. occidentalis are more efficient in transmitting TSWV than are older ones (26).

TABLE 2. Transmission efficiency of a Capsicum chlorosis virus (CaCV) Asian Institute of Technology (AIT) isolate (CaCV-AIT) on tomato leaf disks by adult Ceratothripoides claratris reared from second-instar larvae previously collected from infected tomato plants in a nethouse and adult thrips directly collected from infected tomato plants in a nethouse

\begin{tabular}{lcccc} 
& & \multicolumn{3}{c}{ Mean $\left( \pm\right.$ SE) transmission by adult thrips $(\%)^{\mathrm{z}}$} \\
\cline { 2 - 5 } Source of adult thrips & Repetitions & Female & Male & Total \\
\hline Reared from second-instar larvae & 3 & $86.23 \pm 7.53 \mathrm{Ba}(77)$ & $87.18 \pm 6.78 \mathrm{Ba}(36)$ & $86.54 \pm 7.28 \mathrm{~B}(113)$ \\
Collected as adults from infected plants & 3 & $11.18 \pm 8.02 \mathrm{Aa}(137)$ & $22.50 \pm 11.55 \mathrm{Aa}(70)$ & $15.05 \pm 7.39 \mathrm{~A}(207)$ \\
\hline
\end{tabular}

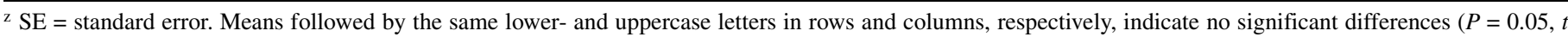
test) (SAS Institute 1999). Numbers in parentheses represent sample sizes. 
In conclusion, $C$. claratris is an efficient vector of transmitting CaCV-AIT. Both first- and second-instar larvae can acquire the virus, and second-instar larvae and adults can transmit the virus. The short life cycle of $C$. claratris, coupled with its high reproductive capacity at high temperatures (10), may lead to serious virus epidemics under tropical conditions.

\section{ACKNOWLEDGMENTS}

This study was funded by the German Research Council (DFG) within the framework of the DFG-FOR 431 project. We thank K. Kittipakorn (Department of Agriculture, Bangkok, Thailand), O. Gajanandana (BIOTEC, Science Park, Bangkok, Thailand), and P. Chiemsombat (Kasetsart University, Kamphaeng Saen, Thailand) for the great cooperation for this research.

\section{LITERATURE CITED}

1. Brittlebank, C. C. 1919. Tomato diseases. J. Agric. Victoria Aust. 17:231235.

2. Clark, M. F., and Adams, A. N. 1977. Characteristics of the microplate method of enzyme linked immunosorbent assay for the detection of plant viruses. J. Gen. Virol. 34:475-483.

3. Francki, R. I. B., and Hatta, T. 1981. Tomato spotted wilt virus. Pages. 492-522 in: Handbook of Plant Virus Infection and Comparative Diagnosis. E. Kurstak, ed. Elsevier North-Holland Biomedical Press, Amsterdam.

4. German, T. L., Ullman, D. E., and Moyer, J. W. 1992. Tospoviruses: Diagnosis, molecular biology, phylogeny and vector relationships. Annu. Rev. Phytopathol. 30:315-348.

5. Kritzman, A., Raccah, B., and Gera, A. 2002. Transmission of Iris yellow spot virus. Pages 95-98 in: Thrips and Tospoviruses. Proc. 7th Int. Symp. Thysanoptera. Australian National Insect Collection, Canberra, Australia.

6. McMichael, L. A., Persley, D. M., and Thomas, J. E. 2002. A new tospovirus serogroup IV species infecting capsicum and tomato in Queensland, Australia. Aust. Plant Pathol. 31:231-239.

7. Moritz, G., Kumm, S., and Mounds, L. 2004. Tospovirus transmission depends on thrips ontogeny. Virus Res. 100:143-149.

8. Murai, T., Kawai, S., Chongratanameteekul, W., and Nakasuji, F. 2000. Damage to tomato by Ceratothripoides claratris (Shumsher) (Thysanoptera: Thripidae) in central Thailand and a note on its parasitoid, Goethena shakespearei Girault (Hymenoptera: Eulophidae). Appl. Entomol. Zool. 35:505-507.

9. Pongsapich, P., and Chiemsombat, P. 2002. Characterization of tospovirus infecting tomatoes in Thailand revealed the presence of serogroup IVtospovirus but not serogroup 1-tomato spotted wilt virus. Page 92 in: Summary, First Int. Conf. Trop. Subtrop. Plant Dis. Chiang Mai, Thailand.

10. Premachandra, W. T. S. D., Borgemeister, C., Chabi-Olaye, A., and Poehling, H.-M. 2004. Influence of temperature on the development, reproduction and longevity of Ceratothripoides claratris (Thysanoptera: Thripidae) on tomatoes. Bull. Entomol. Res. 94:377-384.

11. Resende, R. O., de Ávila, A. C., Goldbach, R. W., and Peters, D. 1991. Comparison of polyclonal antisera in the detection of tomato spotted wilt virus using the double antibody sandwich and cocktail ELISA. J. Phytopathol. 132:46-56.

12. Rodmui, P. 2002. Population dynamics and biological control of thrips, Ceratothripoides claratris (Shumsher) (Thysanoptera: Thripidae), on tomato under protected cultivation in Thailand. M.S. diss. Kasetsart University, Bangkok, Thailand.

13. Sakimura, K. 1962. The present status of thrips-borne viruses. Pages 3340 in: Biological Transmission of Disease Agents. K. Maramorosch, ed. Academic Press, New York.
14. Sakurai, T., Murai, T., Maeda, T., and Hisaaki, T. 1998. Sexual differences in transmission and accumulation of tomato spotted wilt virus in its insect vector Frankliniella occidentalis (Thysanoptera: Thripidae). Appl. Entomol. Zool. 33:583-588.

15. SAS Institute. 1999. SAS/Stat User's Guide, Version 8. SAS Institute, Cary, NC.

16. Tamada, T., and Harrison, B. D. 1981. Quantitative studies on the uptake and retention of potato leafroll virus aphids in laboratory and field conditions. Ann. Appl. Biol. 98:261-276.

17. Tavella, L., Tedeschi, R., Mason, G., and Roggero, P. 2002. Efficiency of north-western Italian thrips populations in transmitting tospoviruses. Pages 81-86 in: Thrips and Tospoviruses. Proc. 7th Int. Symp. Thysanoptera. Australian National Insect Collection, Canberra, Australia.

18. Ullman, D. E. 1996. Thrips and Tospoviruses: Advances and future directions. Acta Hortic. 431:310-324.

19. Ullman, D. E., Cho, J. J., Mau, R. F. L., Hunter, W. B., Westcot, D. M., and Custer, D. M. 1992. Thrips-tomato spotted wilt virus interactions: Morphological, behavioral and cellular components influencing thrips transmission. Pages 195-240 in: Advances in Disease Vector Research. K. F. Harris, ed. Springer-Verlag, New York.

20. Ullman, D. E., German, T. L., Sherwood, J. L., Westcot, D. M., and Cantone, F. A. 1993. Tospovirus replication in insect vector cells immunocytochemical evidence that the nonstructural protein encoded by the SRNA of tomato spotted wilt tospovirus is present in thrips vector cells. Phytopathology 83:456-463.

21. Ullman, D. E., Meideros, R., Campbell, L. R., Whitfield, A. E., Sherwood, J. L., and German, T. L. 2002. Thrips as vectors of tospoviruses. Pages 113-140 in: Advances in Botanical Research; Incorporating Advances in Plant Pathology. R. T. Plumb and J. A. Callow, eds. Academic Press, Elsevier Imprint, San Diego, CA.

22. Ullman, D. E., Westcot, D. M., Chenault, K. D., Sherwood, J. L., German, T. L., Bandla, M. D., Cantone, F. A., and Duer, H. L. 1995. Compartmentalization, intracellular transport and autophagy of tomato spotted wilt tospovirus proteins in infected cells. Phytopathology 85:644-654.

23. Ullman, D. E., Westcot, D. M., Mau, R. F. L., Cho, J. J., and Custer, D. M. 1991. Tomato spotted wilt virus and one thrips vector: Frankliniella occidentalis (Pergande) internal morphology and virus location. Pages 127-136 in: Virus-Thrips-Plant Interaction of Tomato spotted wilt virus. Proc. U.S. Dep. Agric. Workshop. H.-T. Hsu and R. H. Lawson, eds. United States Department of Agriculture, Beltsville, MD.

24. Van de Wetering, F., Goldbach, R., and Peters, D. 1996. Tomato spotted wilt tospovirus ingestion by first instar larvae of Frankliniella occidentalis is a prerequisite for transmission. Phytopathology 86:900-905.

25. Van de Wetering, F., Hulshof, J., Posthuma, K., Harrewijn, P., Goldbach, R., and Peters, D. 1998. Distinct feeding behaviour between sexes of Frankliniella occidentalis results in higher scar production and lower tospovirus transmission by females. Entomol. Exp. Appl. 88:9-15.

26. Van de Wetering, F., van der Hoek, M., Goldbach, R., Mollema, C., and Peters, D. 1999. Variation in tospovirus transmission between populations of Frankliniella occidentalis (Thysanoptera: Thripidae). Bull. Entomol. Res. 89:579-588.

27. Wijkamp, I., Almarza, N., Goldbach, R., and Peters, D. 1995. Distinct levels of specificity in thrips transmission of tospoviruses. Phytopathology 85:1069-1074.

28. Wijkamp, I., Goldbach, R., and Peters, D. 1996. Virus vector interactions of tomato spotted wilt virus in Frankliniella occidentalis is neither accompanied by pathological effects nor by transovarial transmission. Entomol. Exp. Appl. 81:285-292.

29. Wijkamp, I., and Peters, D. 1993. Determination of the median latent period of two tospoviruses in Frankliniella occidentalis, using a novel leaf disk assay. Phytopathology 83:986-991.

30. Wijkamp, I., van Lent, J., Kormelink, R., Goldbach, R., and Peters, D. 1993. Multiplication of tomato spotted wilt virus in its insect vector, Frankliniella occidentalis. J. Gen. Virol. 74:341-349. 